\title{
Is Socially Responsible Investment Outperforming Conventional Investment or Not? A Meta-Analysis
}

\author{
Ouassil AitElMekki1,2 \\ ${ }^{1}$ EDEG, Montpellier Research in Management, Université de Montpellier, Montpellier, France \\ ${ }^{2}$ CRME, HEEC Business School of Marrakech, Marrakech, Morocco \\ Email: o.aitelmekki@uca.ac.ma, o.aitelmekki@eheec.ac.ma
}

How to cite this paper: AitElMekki, O. (2020). Is Socially Responsible Investment Outperforming Conventional Investment or Not? A Meta-Analysis. American Journal of Industrial and Business Management, 10, 1760-1784.

https://doi.org/10.4236/ajibm.2020.1011110

Received: October 29, 2020

Accepted: November 27, 2020

Published: November 30, 2020

Copyright $\odot 2020$ by author(s) and Scientific Research Publishing Inc. This work is licensed under the Creative Commons Attribution-NonCommercial International License (CC BY-NC 4.0).

http://creativecommons.org/licenses/by-nc/4.0/

\begin{abstract}
This meta-analysis provides an overview of the current literature on Socially Responsible Investment (SRI). It presents the underlying motivation, history and current best practices. The in-depth analysis examines a large body of research and addresses two key issues. The first objective was to determine the relative performance of SRI vehicles compared to their conventional benchmarks. The analysis revealed a lack of consensus in previous research. Some studies argue that SRI funds perform as well as, and/or worse than conventional benchmarks, while others challenge these findings. The second objective was to analyse the impact of corporate social responsibility on the company's financial performance. Here, the analysis covered almost four decades, from the 1980s to 2020. It examined more than 100 academic studies, with an overall sampling period that ran from 1960 to 2019. The results provide a solid platform for future work. The study provides researchers with a well-documented, structured overview of the existing literature on SRI, and identifies gaps that could be filled by future studies.
\end{abstract}

\section{Keywords}

Market Finance, Portfolio Management, Responsible Finance, Ethical Finance, Socially Responsible Investment (SRI), Responsible Investment Funds, Conventional Funds, Portfolio Financial Performance, Corporate Social Responsibility (CSR), Environmental, Social and Corporate Governance (ESG) Criteria

\section{Introduction}

The recent financial crisis has highlighted a growing preference for responsible 
investment and the consideration of ethical decisions in finance; the subprime crisis of 2008 (Longstaff, 2010; Demyanyk \& Van Hemert, 2011; Markham, 2015; Taleb \& Khouaja, 2019; Pereira, 2020), manifested itself both in public debates and in the academic literature. Since then, many institutional and private investors have been seeking ways to integrate their social and financial interests. As a result, a significant proportion of investors have adopted Socially Responsible Investment (SRI) principles. In its latest report, the Global Sustainable Investment Alliance (GSIA, 2018) indicates that global SRI reached US\$ 30.7 trillion in the five main markets: Europe ( $€ 12.30 \mathrm{~T}$ ); the United States ( $\$ 12 \mathrm{~T}$ ); Canada (CAD2.13 T); Australia and New Zealand (US\$ $1 \mathrm{~T}$ ) and Japan (¥ $232 \mathrm{~T}$ ), an increase of $34 \%$ in two years. The world's largest sustainable investment strategy continues to be exclusive selection, with a total of $\$ 19.8$ trillion in assets under management. This is followed by a range of environmental, social and governance (ESG) criteria, which have seen investment increase by $69 \%$ over the past two years, reaching \$ 17.5 trillion in assets. Exclusive selection is the most widespread strategy in Europe, while selection based on ESG criteria dominates the majority of assets in the United States, Canada, Australia and New Zealand. In Japan, corporate shareholder and engagement action is the dominant strategy.

Several studies have documented the interest and increased investment in corporate social responsibility (CSR) in the United States, European, Canadian and Australian markets over time (Hockerts \& Moir, 2004; Umlas, 2008; Junkus \& Berry, 2010; Derwall et al., 2011; Bialkowski \& Starks, 2016). This demonstrates the growing interest of investors in integrating ethical and financial concerns into their investments.

The meta-analysis presented here draws on more than 40 years of academic research on SRI and its impact. It aims to provide the reader with a comprehensive overview of the literature, and point out leading research methods in this field. The study provides a well-structured overview of a large body of SRI research and its findings, with a key focus on whether or not SRI is a financially profitable approach. It provides an ideal starting point for future research in this area.

The analysis examines the development of SRI over time, and provides an understanding of the different terms and definitions used by CSR researchers. It also identifies the motivations of different groups of investors to include CSR in their investment decisions. It explains the different methods, and how they can be put into practice. It then addresses two major issues in the academic literature: firstly, if the financial performance of CSR investments does compare favourably with conventional investments, does this motivate investors to act? Secondly, are CSR strategies profitable for the companies themselves? This meta-analysis also provides an overview of the different methods and parameters currently available, and identifies the regional focus and time period of the empirical studies reviewed. It outlines more recent areas of research, such as CSR investment ratings, and multi-attribute portfolio optimisation. Finally, it sum- 
marises the findings, and offers an overview of potentially interesting future research topics.

\section{Development, Rationale and Current Implementation of SRIs}

\subsection{Historical Development}

Even in ancient Rome, wise men sought to distinguish themselves in all aspects of their lives, including trade. It could be said that the Bible, and the Torah established the first rules for ethical investment. In the $7^{\text {th }}$ century, the Quran (the sacred text of the Muslims) and the Hadith (the record of the traditions or sayings of the Prophet Muhammad) are an extension of the same philosophy. Islam provides clear guidance for commercial life, in the form of ethical stipulations (sharia or Islamic jurisprudence Al-Fiqh). In the middle of the $18^{\text {th }}$ century, the Methodist Church sought to do the same (Peifer, 2012). As early as 1948, the Methodist Church and the Church of England in the United Kingdom set up investment portfolios that took into account ethical constraints (Bengtsson, 2008). But the first, true SRI fund was the Pioneer Fund of Boston in 1928, in the United States, founded by a church group (Kirchhoff, 2008). In the 1900s, the equity market began to focus more on the religious requirements of the Islamic community, for example, by excluding specific sectors from investment portfolios, notably practices such as the sale of alcohol, tobacco, sex, pork, usury, gambling, etc. (Warde, 2000; El-Gamal, 2006; Ariff \& Iqbal, 2011; Iqbal \& Mirakhor, 2011; Ayub, 2013; Alim, 2014; Visser, 2019). At the same time, concerns have grown regarding environmental issues (Fung et al., 2010; Bilbao-Terol et al., 2016). Investment decisions initially followed a simple triangular path of liquidity, risk and return. Today, a growing number of investors use the magic square: liquidity, risk, return and sustainability. This can be seen as an improvement to the neoclassical homo economicus, who is motivated solely by economics (Duttweiler, 2011; Bernstein, 2020).

\subsection{Definitions and Terminology}

There is great heterogeneity in the current academic literature regarding the terminology to be used to refer to the type of investment discussed in this study. Chatzitheodorou et al. (2019) conducted a literature review focused on the issue of the terminology used to define this type of investment, and observed that the majority of the literature focuses on SRI performance compared to conventional investment. The authors argued that, despite the plurality of terms (e.g. sustainable, ethical, environmental and social) that have been invented to explain the reasoning behind SRI, they all relate to an overarching definition. Specifically, they are based on the assumption that SRI undermines the precision and robustness of existing metrics, as only some aspects of global performance are assessed. Although a consensus has not yet emerged in the literature, typical terms are SRI, social, sustainable, green, ethical or alternative investment (Nilsson, 
2008). Although there are inconsistencies in their use, some authors (Guay et al., 2004; Arjaliès, 2010; Bilbao-Terol et al., 2016) consider SRI definitions to be consistent to the extent that they refer to the integration of non-financial concerns, such as environmental, social or governance, into investments. This paper adopts the most widely-used term-SRI.

While SRI defines the active task of investing responsibly, the term corporate social responsibility (CSR) is used in the academic literature to describe a company's ethical and responsible behaviour (Whitehouse, 2006). It considers that firms should combine environmental and social questions into their corporate governance. By applying CSR policies, companies seek to attract CSR investors (Teoh \& Shiu, 1990). Conversely, shareholders can use their voting rights to steer the company's management in a more CSR-oriented direction (Griseri \& Seppala, 2010; Glac, 2014).

\subsection{SRI Performance}

When it comes to estimating the performance of SRI compared to conventional funds, the literature reports mixed findings. At the same time, there is a large body of research on the relationship between financial performance and SRI. From a technical point of view, two major orientations can be adopted to assess the financial performance of SRI: (1) the comparison of the financial performance of SRI funds with conventional counterparts that have the same characteristics with respect to capitalisation, time horizons, economic zones, etc.; and (2) the comparison of the financial performance of SRI funds with the market, using a model.

Some studies report the results of regression analyses, seeking to provide an explanation for the factors that influence returns, including ethical commitment. One-, two- and four-factor models, such as the Capital Asset Pricing Model (CAPM), the Fama-French and Carhart models have been used. The CAPM considers market risk (beta) as an explanatory factor for asset price movements (Markowitz, 1952). Fama \& French (1993) added two other factors to the CAPM: size and book-to-market value. The Carhart model is based on the three-factor Fama-French model, but adds a fourth factor. The latter captures the momentum anomaly, i.e. the difference in return between winners and losers over the past 12 months (Jegadeesh \& Titman, 1993; Carhart, 1997). A comparison of SRI with conventional funds must ensure that they have similar characteristics, to minimise size or style effects when comparing returns. Various comparison methods are in use, which differ in terms of: (1) the choice of performance measures; and (2) benchmarks. These two factors are very important in determining the performance of SRI investments and their conventional counterparts. It should be noted that many studies use more than one performance measure.

Other researchers have adopted a different approach, with the same goal. Thus, some studies use the Treynor ratio (1965), Sharpe's ratio (1966), Jensen's 
alpha (1967), or Tobin's Q (1969). Another practice is to use the excess standard deviation adjusted return (eSDAR). This was applied by Statman (2000) which estimated the additional return at a specific point in time from a portfolio, using the same risk rate as the benchmark.

One of the main objectives of performance measurement is to find an appropriate benchmark against which to compare a portfolio. In the world of market finance, this concerns the main sustainability indices, the selection methods used, and the benchmarks underlying them. The most well-known and important indices are: (1) KLD's Domini Social Index; (2) the Dow Jones Sustainability Index (López et al., 2007; Searcy \& Elkhawas, 2012), both based in the United States; and (3) the FTSE4Good Index, based in the United Kingdom (Martin, Curran, \& Moran, 2007; Collison et al., 2008, 2009). The Domini 400 Social Index (sometimes called the KLD 400 Index, as it was established by Kinder, Lydenberg \& Domini) is one of the best-known social indices (Corson \& Dyck, 1992; Sauer, 1997). Launched in March 1990, it is considered to be the first general stock market index in the United States designed to measure the performance of portfolios subject to multiple religious (notably, Catholic) and social constraints (Kurtz \& di Bartolomeo, 2005; Statman, 2006; Ramchander et al., 2012).

\section{Does SRI Out- (Under-)Perform Conventional Investment?}

Research conducted over the past four decades clearly demonstrates a growing interest in SRI. It emerged from the meta-analysis that the vast majority of published papers relate to the measurement of SRI performance. This can be explained by the fact that this area of research is very much focused on quantitative data, as well as its accessibility. More recently, the SRI literature has moved away from performance measurement, to focus on other, qualitative, variables. The latter includes a diverse range of factors. Interest in stakeholders, ESG criteria, sustainability, activism, etc. has grown considerably over this time. It is not surprising that more than 100 academic studies, including 70 research papers, in the dataset were dedicated to the measurement and comparison of SRI fund performance with a benchmark.

In the world of responsible finance, the literature lacks a consensus regarding the measurement of the performance of SRI funds compared to conventional funds, market indices or benchmark funds. This meta-analysis only focuses on empirical studies of market data, and not those based on accounting data, or those that present a theoretical model. Specifically, the dataset consists of 103 empirical studies of SRI; of these, 33 identify relationships between a specific behaviour that is perceived as responsible (or not), and the financial performance of a single firm. The aim is to show whether CSR behaviour is financially beneficial for the firm.

The overall analysis focused primarily on studies published during the past 40 years (between the 1980s and 2020), with a 60-year sample period running from 1960 to 2019. The aim was to identify trends in empirical analyses (Table 1). 
The dataset of studies can be categorised as a function of their findings regarding the comparison of SRI performance with benchmarks. Indices or ethical funds may underperform, outperform or perform equally well as conventional funds and indices, or performance can be considered as a function of market conditions. As shown in Table 1 and Figure 1, of the 70 studies that compare the performance of SRIs with benchmarks, 25 conclude that SRIs perform in the same (or almost the same) way as conventional benchmarks, 12 find underperformance, 23 find outperformance and, finally, 10 attribute SRI performance to market behaviour during crisis and non-crisis periods. The meta-analysis verified these results, and concluded that data followed a normal distribution, with a coefficient of determination $\left(\mathrm{R}^{2}\right)$ equal to 0.82 . Figure 1 shows the articles that were reviewed, highlighting the four relationships.

Sampling periods differed for each study. In articles that reported the underperformance of SRIs, the mean sampling period was 10 years. The shortest period, two years (1999-2001), was recorded by Geczy et al., (2005), and the longest, 20 years (1995-2015), was reported by Kiymaz (2019a). With respect to papers that demonstrated similar performance, the mean sampling period was nine years; the shortest, two years (2000-2002), was reported by Schröder (2004) and the longest, 22 years (1982-2004), was noted by Mill (2006). In contrast, studies found that SRIs outperformed their counterparts, the mean sampling period

Table 1. Studies considered in the meta-analysis.

\begin{tabular}{|c|c|c|}
\hline Background & & Total \\
\hline SRI performance vs the benchmark & Similar (or almost) & 25 ref. \\
\hline (70 references) & Underperformance & 12 ref. \\
\hline (Publications date: 1980 s-2020) & Outperformance & 23 ref. \\
\hline (Sampling period: 1960-2019) & Market behaviour & 10 ref. \\
\hline Relationship SRI-ESG (Sampling period: 1990s-2020) & & 33 ref. \\
\hline Total & & 103 ref. \\
\hline
\end{tabular}

Source: Author's survey.

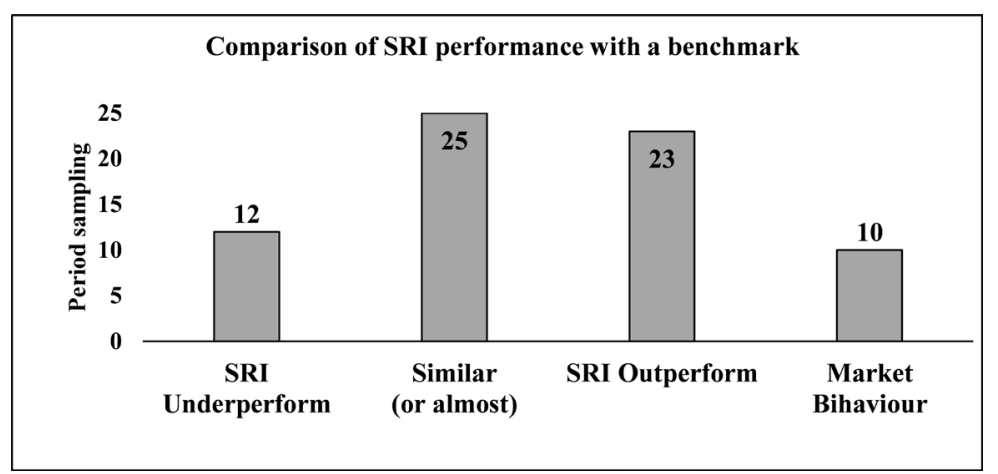

Source: Author's survey.

Figure 1. Results of the comparison of SRI performance with a benchmark in the reviewed articles. 
was eight years; the shortest period, one year (1999), was identified in Epstein \& Schnietz (2002) and the longest period, 23 years, was reported by two studies Grossman \& Sharpe (1986) and Ibikunle \& Steffen (2017). In the latter case, sampling periods were 1960-1983 and 1991-2014, respectively. These statistics were summarised in Table 2 and Figure 2. The full set of articles that made up

Table 2. Statistics for studies considered in this meta-analysis.

\begin{tabular}{cccc}
\hline Comparative SRI performance & $\begin{array}{c}\text { Period average } \\
\text { (sampling) }\end{array}$ & $\begin{array}{c}\text { Minimum period } \\
\text { (sampling) }\end{array}$ & $\begin{array}{c}\text { Maximum period } \\
\text { (sampling) }\end{array}$ \\
\hline Similar (or almost) & 9.12 years & 2 years & 22 years \\
Underperformance & 9.91 years & 2 years & 20 years \\
Outperformance & 8.13 years & 1 year & 23 years \\
Average & 9.06 years & 2.34 years & 22.67 years \\
\hline
\end{tabular}

Source: Author's survey

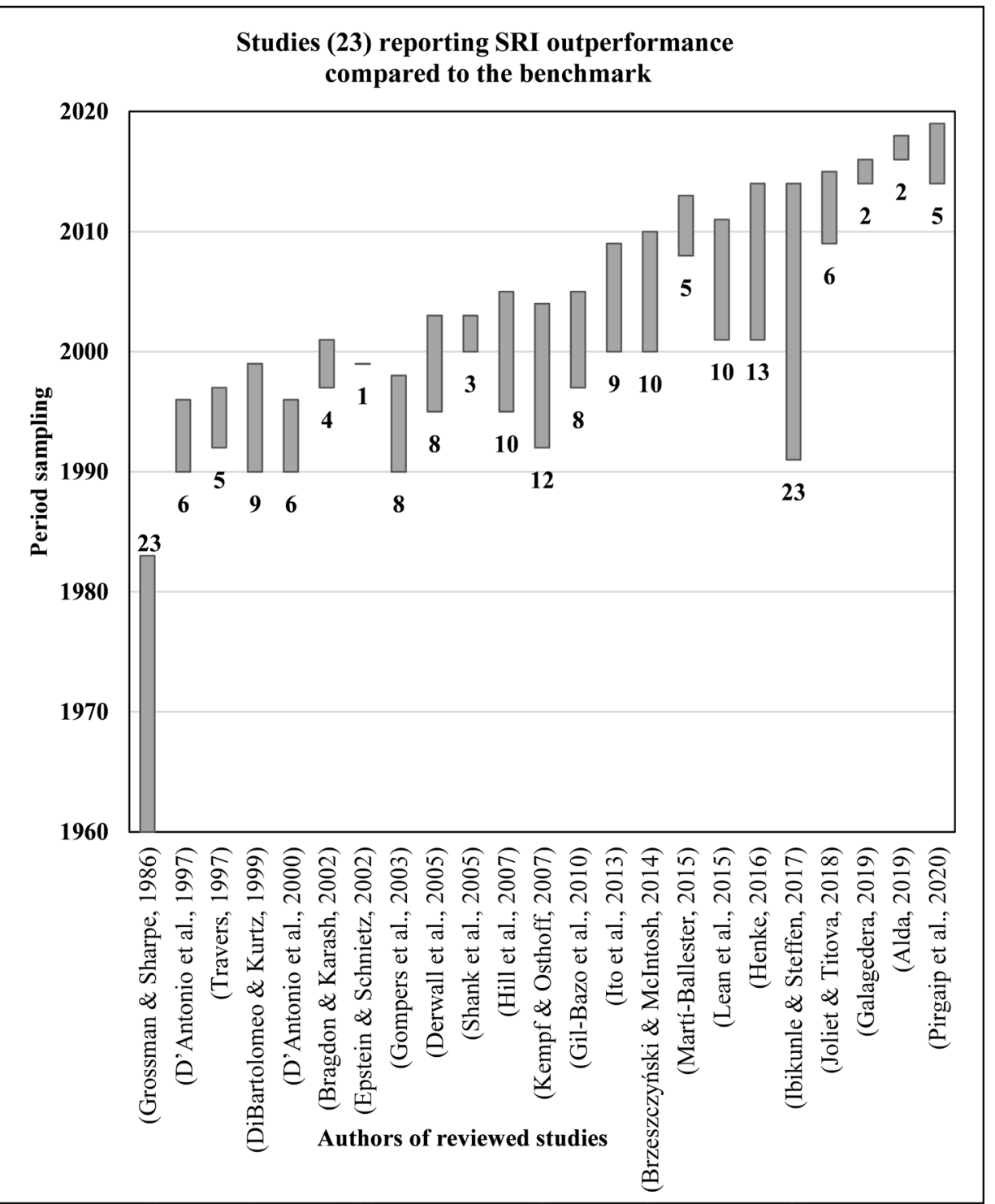




\section{Continued}

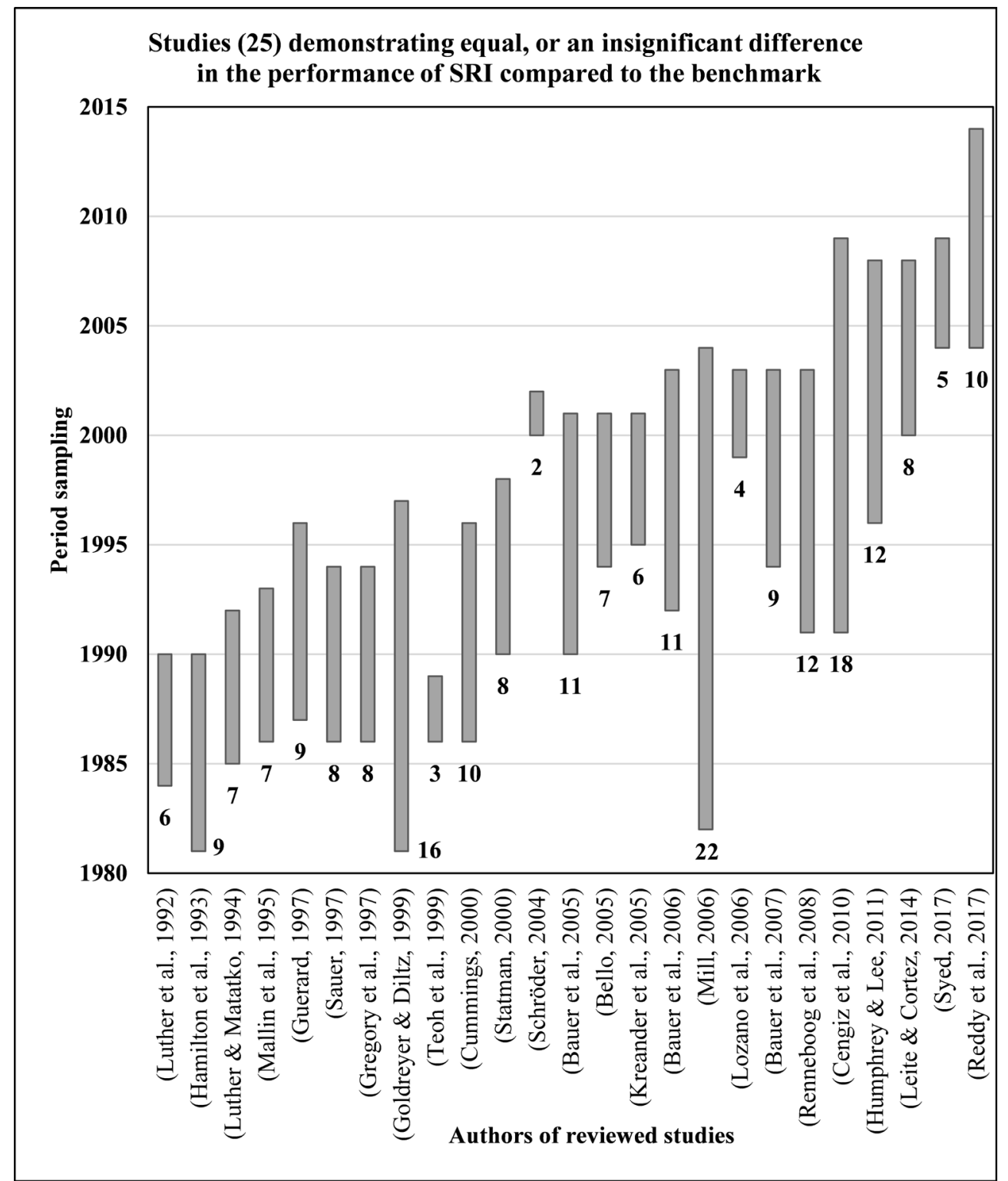




\section{Continued}

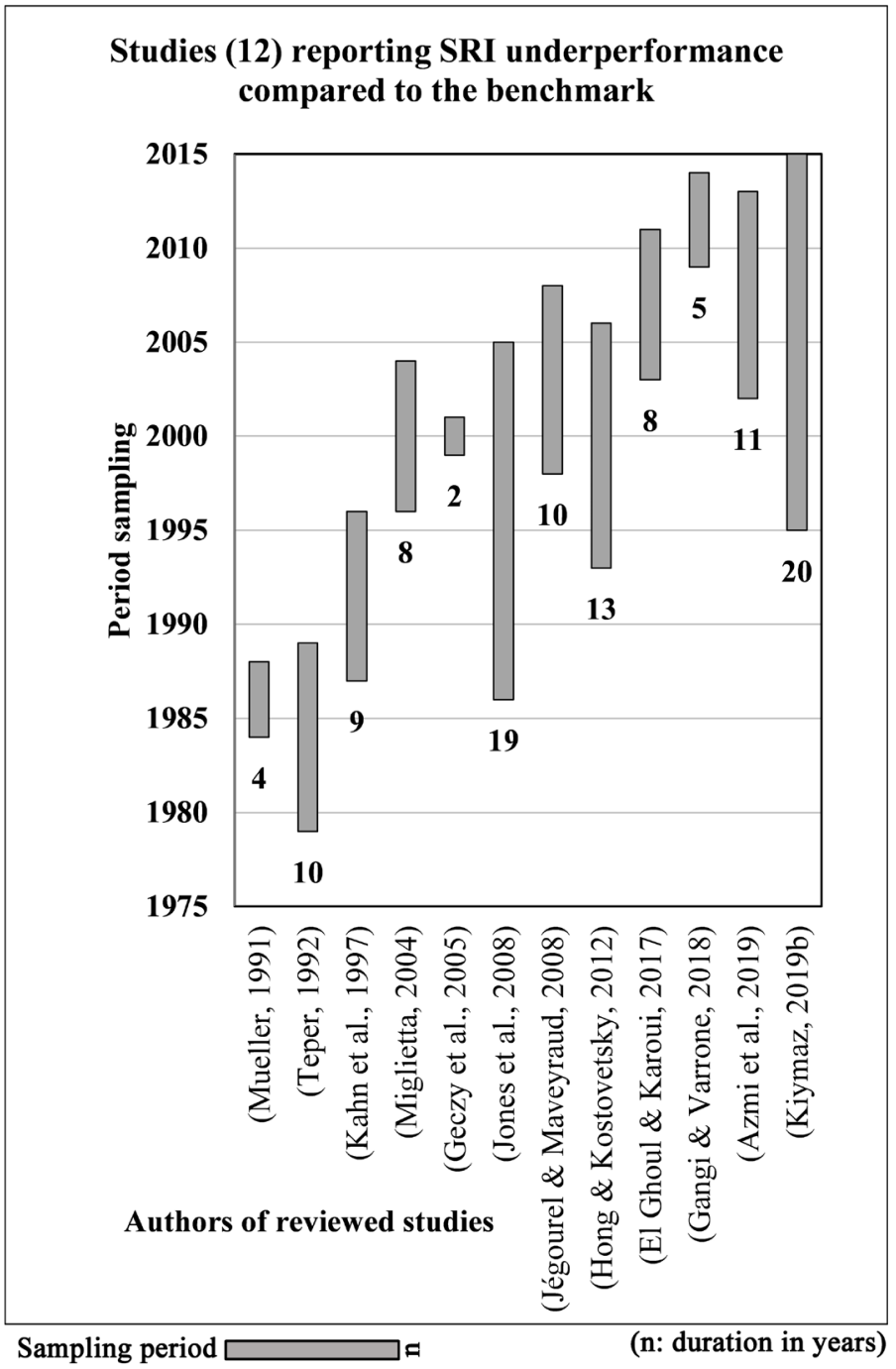

Source: Author's survey.

Figure 2. Sampling period of studies demonstrating similar, and out- (under-)performance of SRIs included in this meta-analysis.

the dataset of this study, and that were not cited above, were reported in Figure 2 and Tables 3-5. Figure 2 presents the sampling period of each study as a function of the authors.

Ten of the 70 studies attributed SRI performance to the market situation, economic conditions and crisis (or non-crisis) periods. An exception is Rathner (2013) which attributed it to survivorship bias, while Leite \& Cortez (2015) and Trinks \& Scholtens (2017) showed that SRIs performed well compared to their conventional counterparts in times of crisis, but underperformed in non-crisis periods. On the other hand, Omri et al. (2019) does not support this finding. Among the remainder of the articles, six studies (See Table 6) showed that all SRI funds outperformed conventional funds in booming economic conditions, while they underperformed during quiet periods. 
Table 3. Studies (25) demonstrating equal, or an insignificant difference in the performance of SRI compared to the benchmark.

\begin{tabular}{|c|c|}
\hline References & Sampling period \\
\hline (Luther et al., 1992) & 1984-1990 \\
\hline (Hamilton et al., 1993) & $1981-1990$ \\
\hline (Luther \& Matatko, 1994) & 1985-1992 \\
\hline (Mallin et al., 1995) & $1986-1993$ \\
\hline (Guerard, 1997) & $1987-1996$ \\
\hline (Sauer, 1997) & 1986-1994 \\
\hline (Gregory et al., 1997) & 1986-1994 \\
\hline (Goldreyer \& Diltz, 1999) & 1981-1997 \\
\hline (Teoh et al., 1999) & 1986-1989 \\
\hline (Cummings, 2000) & 1986-1996 \\
\hline (Statman, 2000) & 1990-1998 \\
\hline (Schröder, 2004) & $2000-2002$ \\
\hline (Bauer et al., 2005) & $1990-2001$ \\
\hline (Bello, 2005) & $1994-2001$ \\
\hline (Kreander et al., 2005) & $1995-2001$ \\
\hline (Bauer et al., 2006) & $1992-2003$ \\
\hline (Mill, 2006) & $1982-2004$ \\
\hline (Lozano et al., 2006) & $1999-2003$ \\
\hline (Bauer et al., 2007) & $1994-2003$ \\
\hline (Renneboog et al., 2008) & $1991-2003$ \\
\hline (Cengiz et al., 2010) & 1991-2009 \\
\hline (Humphrey \& Lee, 2011) & $1996-2008$ \\
\hline (Leite \& Cortez, 2014) & $2000-2008$ \\
\hline (Syed, 2017) & 2004-2009 \\
\hline (Reddy et al., 2017) & 2004-2014 \\
\hline
\end{tabular}

(Sorted by publication date); Source: Author's survey.

Table 4. Studies (12) reporting SRI underperformance compared to the benchmark.

\begin{tabular}{cc}
\hline References & Sampling period \\
\hline (Mueller, 1991) & $1984-1988$ \\
$($ Teper, 1992) & $1979-1989$ \\
$($ Kahn et al., 1997) & $1987-1996$ \\
$($ Miglietta, 2004) & $1996-2004$ \\
$($ Geczy et al., 2005) & $1999-2001$ \\
$($ Jones et al., 2008) & $1986-2005$ \\
(Jégourel \& Maveyraud, 2008) & $1998-2008$ \\
(Hong \& Kostovetsky, 2012) & $1993-2006$ \\
(El Ghoul \& Karoui, 2017) & $2003-2011$ \\
(Gangi \& Varrone, 2018) & $2009-2014$ \\
(Azmi et al., 2019) & $2002-2013$ \\
(Kiymaz, 2019b) & $1995-2015$ \\
\hline
\end{tabular}

(Sorted by publication date); Source: Author's survey. 
Table 5. Studies (23) reporting SRI outperformance compared to the benchmark.

\begin{tabular}{|c|c|}
\hline References & Sampling period \\
\hline (Grossman \& Sharpe, 1986) & $1960-1983$ \\
\hline (D’Antonio et al., 1997) & $1990-1996$ \\
\hline (Travers, 1997) & $1992-1997$ \\
\hline (DiBartolomeo \& Kurtz, 1999) & 1990-1999 \\
\hline (D’Antonio et al., 2000) & $1990-1996$ \\
\hline (Bragdon \& Karash, 2002) & $1997-2001$ \\
\hline (Epstein \& Schnietz, 2002) & 1999 \\
\hline (Gompers et al., 2003) & $1990-1998$ \\
\hline (Derwall et al., 2005) & $1995-2003$ \\
\hline (Shank et al., 2005) & $2000-2003$ \\
\hline (Hill et al., 2007) & $1995-2005$ \\
\hline (Kempf \& Osthoff, 2007) & $1992-2004$ \\
\hline (Gil-Bazo et al., 2010) & $1997-2005$ \\
\hline (Ito et al., 2013) & $2000-2009$ \\
\hline (Brzeszczyński \& McIntosh, 2014) & $2000-2010$ \\
\hline (Martí-Ballester, 2015) & $2008-2013$ \\
\hline (Lean et al., 2015) & 2001-2011 \\
\hline (Henke, 2016) & $2001-2014$ \\
\hline (Ibikunle \& Steffen, 2017) & $1991-2014$ \\
\hline (Joliet \& Titova, 2018) & $2009-2015$ \\
\hline (Galagedera, 2019) & 2014-2016 \\
\hline (Alda, 2019) & 2016-2018 \\
\hline (Pirgaip et al., 2020) & 2014-2019 \\
\hline
\end{tabular}

(Sorted by publication date); Source: Author's survey.

Table 6. Studies (10) reporting that SRI performance is a function of market behaviour and economic conditions.

\begin{tabular}{ccc}
\hline References & Crisis & Non-crisis \\
\hline (Rathner, 2013) & According to survivor bias \\
$($ Nofsinger \& Varma, 2014) & $>$ & $<$ \\
$($ Leite \& Cortez, 2015) & $=$ & $<$ \\
$($ Lesser et al., 2016) & $>$ & $<$ \\
$($ Silva \& Cortez, 2016) & $>$ & $<$ \\
$($ Trinks \& Scholtens, 2017) & $=$ & $<$ \\
$($ Omri et al., 2019) & $>$ & $<$ \\
$($ Ielasi \& Rossolini, 2019) & $>$ & $<$ \\
(Arefeen \& Shimada, 2020) & $>$ & $<$ \\
(Dopierała et al., 2020) & $>$ & $<$ \\
\hline
\end{tabular}

(Sorted by publication date); Source: Author's survey. Note: = SRI funds perform equally well (or with an insignificant difference) as the benchmark; > SRI funds outperform the benchmark; < SRI funds underperform compared to the benchmark. 


\section{Impact of ESG Criteria on Company Performance}

As discussed earlier, most studies construct SRI portfolios and then compare them to a counterpart, conventional portfolio or index. However, another approach is to look at the value of a single company to determine the effects of socially responsible behaviour, most often referred to as CSR. There are two ways to measure the value of a company: using accounting data or market data. Most studies focus on market value, determined by the company's share price multiplied by the number of shares outstanding, as the aim is to determine the impact of CSR on both shareholder behaviour and profits. Heiduk \& McCaleb (2014) and Gatti \& Seele (2015) argue that there is a wide gap in the performance of CSR-aware European companies, compared to Asian and American companies. This is claimed to be due to differences in culture and history, as European investors seem to place higher value on SRI than Asian and American investors (Auer \& Schuhmacher, 2016).

There are two approaches to determining whether CSR companies are more valuable than conventional companies. For example, event studies have demonstrated that share prices rise when a company receives a social, environmental or governance award; conversely, if there is information or a scandal related to one, or a set of CSR criteria, share prices fall significantly. Even a simple, explicit commitment to ethical behaviour can have a positive effect on the company's financial performance (Kolk, 2016). Most event studies analyse specific CSR characteristics, such as social or environmental. A positive relationship has been demonstrated between a company's financial performance and the integration of environmental issues into its strategic planning (Shahzad et al., 2020). Furthermore, a positive relationship has been found between the level of environmental information provided by a company, and its financial performance. Other studies have looked at environmental relationships, and the relationship between financial performance and the treatment of stakeholders (such as society, government, customers, suppliers, shareholders, creditors, managers and employees).

This meta-analysis provides a good overview of the state of CSR. It examined 33 academic studies dealing with the topic that report different results. The selected studies were presented in Table 7 and Figure 3. Eighty-four per cent of studies find a positive correlation between financial performance and the adoption of ESG criteria, while the remaining $16 \%$ note a negative correlation. The overall, mean sampling period for all studies is around 7.5 years. Research that identifies a positive correlation has a mean sampling period of eight years; the shortest period, one year, was reported in six studies (see Table 7), and the longest period, 40 years (1970-2010), was reported by (Friede et al., 2015). With respect to studies that find a negative correlation, the mean sampling period is four years; the shortest period, one year (1986), was reported by (Boyle et al., 1997), and the longest period, eight years (2002-2010), was noted by (Humphrey et al., 2012). Full references for the articles making up the dataset, which were not cited 


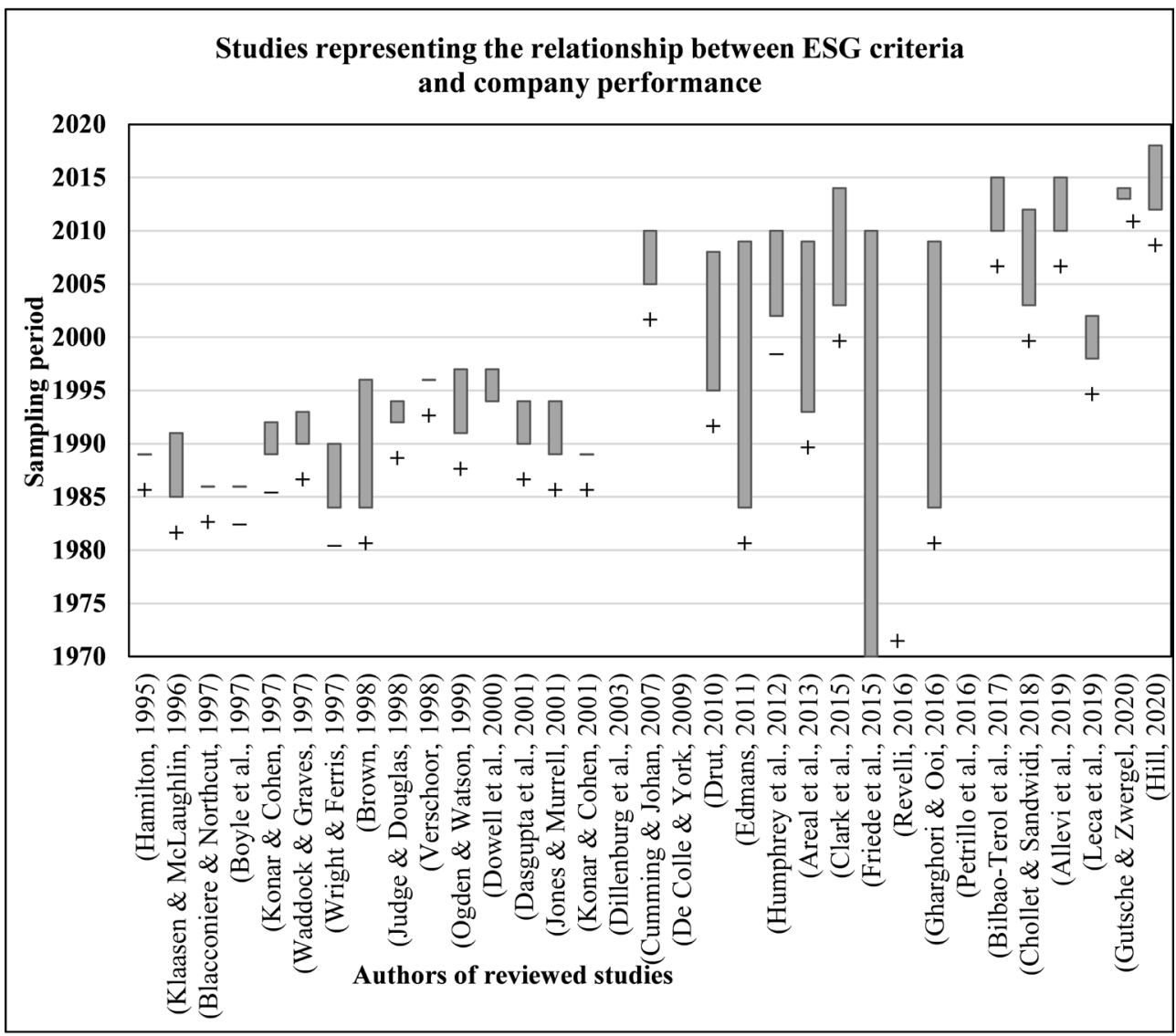

Sampling period

Source: Author's survey. Note: + relationship; - not relationship.

Figure 3. Sampling period of studies representing the relationship (or not) between ESG criteria and company performance included in this meta-analysis.

above, were reported in Table 7 and Figure 3.

\section{Conclusion}

This meta-analysis outlined the reasons for the increased interest that institutional and private investors are showing in incorporating ethical concerns into financial decision-making. The analysis examined a large body of empirical research, and outlined the ongoing discussions in the academic literature regarding the performance of SRI investments. The findings indicate that the majority of the current academic literature reports that the performance of SRI funds is on par with conventional investments. At the same time, many studies show that SRI investments outperform conventional instruments, while others have found that they underperform. The analysis highlighted studies that sought to determine the relationship between a company's financial performance and its efforts to implement CSR policies. Overall, most studies found that the integration of ESG criteria has a positive effect on financial results.

This initial study could form the basis for future research. It deepens knowledge related to SRI investments and the ambiguities surrounding this increasingly 
Table 7. Studies (33) that report a relationship (or not) between ESG criteria and company performance.

\begin{tabular}{|c|c|c|}
\hline References & Sampling period & Relationship \\
\hline (Hamilton, 1995) & 1989 & Yes \\
\hline (Klaasen \& McLaughlin, 1996) & 1985-1991 & Yes \\
\hline (Blacconiere \& Northcut, 1997) & 1986 & Yes \\
\hline (Boyle et al., 1997) & 1986 & No \\
\hline (Konar \& Cohen, 1997) & 1989-1992 & No \\
\hline (Waddock \& Graves, 1997) & $1990-1993$ & Yes \\
\hline (Wright \& Ferris, 1997) & 1984-1990 & No \\
\hline (Brown, 1998) & 1984-1996 & Yes \\
\hline (Judge \& Douglas, 1998) & 1992-1994 & Yes \\
\hline (Verschoor, 1998) & 1996 & Yes \\
\hline (Ogden \& Watson, 1999) & 1991-1997 & Yes \\
\hline (Dowell et al., 2000) & 1994-1997 & Yes \\
\hline (Dasgupta et al., 2001) & 1990-1994 & Yes \\
\hline (Jones \& Murrell, 2001) & 1989-1994 & Yes \\
\hline (Konar \& Cohen, 2001) & 1989 & Yes \\
\hline (Dillenburg et al., 2003) & - & Yes \\
\hline (Cumming \& Johan, 2007) & 2005 \& forecast $2006-2010$ & Yes \\
\hline (De Colle \& York, 2009) & - & No \\
\hline (Drut, 2010) & $1995-2008$ & Yes \\
\hline (Edmans, 2011) & 1984-2009 & Yes \\
\hline (Humphrey et al., 2012) & $2002-2010$ & No \\
\hline (Areal et al., 2013) & 1993-2009 & Yes \\
\hline (Clark et al., 2015) & 2003-2014 & Yes \\
\hline (Friede et al., 2015) & 1970s-2010s & Yes \\
\hline (Revelli, 2016) & - & Yes \\
\hline (Gharghori \& Ooi, 2016) & 1984-2009 & Yes \\
\hline (Petrillo et al., 2016) & - & Yes \\
\hline (Bilbao-Terol et al., 2017) & 2010-2015 & Yes \\
\hline (Chollet \& Sandwidi, 2018) & 2003-2012 & Yes \\
\hline (Allevi et al., 2019) & 2010-2015 & Yes \\
\hline (Leca et al., 2019) & 1998-2002 & Yes \\
\hline (Gutsche \& Zwergel, 2020) & 2013-2014 & Yes \\
\hline (Hill, 2020) & 2012-2018 & Yes \\
\hline
\end{tabular}

(Sorted by publication date); Source: Author's survey. 
popular type of ethical finance. Finally, from a broader perspective, this metaanalysis is a valuable resource for researchers, as it summarises, in a few pages, the current state of knowledge in the field. It adopts a spatiotemporal view, spanning almost four decades, from the 1980s to 2020, and examines more than 100 academic studies, over a sampling period that runs from 1960 to 2019. Data come from all four continents, and shed light on the academic and professional evolution of practices related to responsible finance-the results provide interesting insights into future trends. From an epistemological point of view, it will not only be useful for researchers working in this field but also, and more generally, science historians.

\section{Funding}

This research did not receive any funding, either internal or external.

\section{Tribute to My Father}

In memory of Sir. Abdelmajid AitElMekki ben Belkhir (1955-2018), my father.

You are missed, you are loved and you are remembered every moment of every day for I would not have the life I do without your love and lessons.

\section{Acknowledgements}

The author would like to thank Mrs. Lala Nouzha Boukhari Hariss bent Moulay Ahmed, my mother, for her unconditional love, upbringing and support.

\section{Conflicts of Interest}

The author declares no conflicts of interest regarding the publication of this paper.

\section{References}

Alda, M. (2019). ESG Fund Scores in UK SRI and Conventional Pension Funds: Are the ESG Concerns of the SRI Niche Affecting the Conventional Mainstream? Finance Research Letters, 36, Article ID: 101313. https://doi.org/10.1016/j.frl.2019.101313

Alim, E. A. (2014). Global Leaders in Islamic Finance: Industry Milestones and Reflections. Hoboken, NJ: John Wiley \& Sons.

Allevi, E., Basso, A., Bonenti, F. et al. (2019). Measuring the Environmental Performance of Green SRI Funds: A DEA Approach. Energy Economics, 79, 32-44. https://doi.org/10.1016/j.eneco.2018.07.023

Areal, N., Cortez, M. C., \& Silva, F. (2013). The Conditional Performance of US Mutual Funds over Different Market Regimes: Do Different Types of Ethical Screens Matter? Financial Markets and Portfolio Management, 27, 397-429. https://doi.org/10.1007/s11408-013-0218-5

Arefeen, S., \& Shimada, K. (2020). Performance and Resilience of Socially Responsible Investing (SRI) and Conventional Funds during Different Shocks in 2016: Evidence from Japan. Sustainability, 12, 540. https://doi.org/10.3390/su12020540

Ariff, M., \& Iqbal, M. (2011). The Foundations of Islamic Banking: Theory, Practice and Education. Cheltenham: Edward Elgar Publishing. https://doi.org/10.4337/9781849807937 
Arjaliès, D.-L. (2010). A Social Movement Perspective on Finance: How Socially Responsible Investment Mattered. Journal of Business Ethics, 92, 57-78. https://doi.org/10.1007/s10551-010-0634-7

Auer, B. R., \& Schuhmacher, F. (2016). Do Socially (Ir)Responsible Investments Pay? New Evidence from International ESG Data. The Quarterly Review of Economics and Finance, 59, 51-62. https://doi.org/10.1016/j.qref.2015.07.002

Ayub, M. (2013). Understanding Islamic Finance. Jakarta: Gramedia Pustaka Utama. https://doi.org/10.1002/9781119209096

Azmi, W., Mohamad, S., \& Shah, M. E. (2019). Ethical Investments and Financial Performance: An International Evidence. Pacific-Basin Finance Journal, 62, Article ID: 101147. https://doi.org/10.1016/j.pacfin.2019.05.005

Bauer, R., Derwall, J., \& Otten, R. (2007). The Ethical Mutual Fund Performance Debate: New Evidence from Canada. Journal of Business Ethics, 70, 111-124. https://doi.org/10.1007/s10551-006-9099-0

Bauer, R., Koedijk, K., \& Otten, R. (2005). International Evidence on Ethical Mutual Fund Performance and Investment Style. Journal of Banking and Finance, 29, 1751-1767. https://doi.org/10.1016/j.jbankfin.2004.06.035

Bauer, R., Otten, R., \& Rad, A. T. (2006). Ethical Investing in Australia: Is There a Financial Penalty? Pacific-Basin Finance Journal, 14, 33-48.

https://doi.org/10.1016/j.pacfin.2004.12.004

Bello, Z. Y. (2005). Socially Responsible Investing and Portfolio Diversification. The Journal of Financial Research, 28, 41-57. https://doi.org/10.1111/j.1475-6803.2005.00113.x

Bengtsson, E. (2008). A History of Scandinavian Socially Responsible Investing. Journal of Business Ethics, 82, 969-983. https://doi.org/10.1007/s10551-007-9606-y

Bernstein, C. (2020). Performance Comparison of Sustainable and Conventional EXchange Traded Funds for German Private Investors.

Bialkowski, J., \& Starks, L. T. (2016). SRI Funds: Investor Demand, Exogenous Shocks and ESG Profiles.

Bilbao-Terol, A., Álvarez-Otero, S., Bilbao-Terol, C., \& Cañal-Fernández, V. (2017). Hedonic Evaluation of the SRI Label of Mutual Funds Using Matching Methodology. International Review of Financial Analysis, 52, 213-227.

https://doi.org/10.1016/j.irfa.2017.06.003

Bilbao-Terol, A., Arenas-Parra, M., Cañal-Fernández, V., \& Bilbao-Terol, C. (2016). Multi-Criteria Decision Making for Choosing Socially Responsible Investment within a Behavioral Portfolio Theory Framework: A New Way of Investing into a Crisis Environment. Annals of Operations Research, 247, 549-580.

https://doi.org/10.1007/s10479-015-1947-9

Blacconiere, W. G., \& Northcut, W. D. (1997). Environmental Information and Market Reactions to Environmental Legislation. Journal of Accounting, Auditing and Finance, 12, 149-178. https://doi.org/10.1177/0148558X9701200203

Boyle, E. J., Higgins, M. M., \& Rhee, G. S. (1997). Stock Market Reaction to Ethical Initiatives of Defense Contractors: Theory and Evidence. Critical Perspectives on Accounting, 8, 541-561. https://doi.org/10.1006/cpac.1997.0124

Bragdon, J. H., \& Karash, R. (2002). Living-Asset Stewardship: How Organizational Learning Leads to Exceptional Market Returns. https://doi.org/10.1162/152417302320467562

Brown, B. (1998). Do Stock Market Investors Reward Companies with Reputations for 
Social Performance? Corporate Reputation Review, 1, 271-280.

https://doi.org/10.1057/palgrave.crr.1540048

Brzeszczyński, J., \& McIntosh, G. (2014). Performance of Portfolios Composed of British SRI Stocks. Journal of Business Ethics, 120, 335-362.

https://doi.org/10.1007/s10551-012-1541-x

Carhart, M. M. (1997). On Persistence in Mutual Fund Performance. The Journal of Finance, 52, 57-82. https://doi.org/10.1111/j.1540-6261.1997.tb03808.x

Cengiz, C. B., Braun, D., \& Nitzsch, R. V. (2010). Alpha-Vehikel oder Preis für das gute Gewissen? Eine Performanceanalyse ethischer Investments. Corporate Finance Biz. Finanzmanagement, Bewertung, Kapitalmarkt 1(4), 263-271.

http://publications.rwth-aachen.de/record/194830?ln=de

Chatzitheodorou, K., Skouloudis, A., Evangelinos, K., \& Nikolaou, I. (2019). Exploring Socially Responsible Investment Perspectives: A Literature Mapping and an Investor Classification. Sustainable Production and Consumption, 19, 117-129. https://doi.org/10.1016/j.spc.2019.03.006

Chollet, P., \& Sandwidi, B. W. (2018). CSR Engagement and Financial Risk: A Virtuous Circle? International Evidence. Global Finance Journal, 38, 65-81.

https://doi.org/10.1016/j.gfj.2018.03.004

Clark, G. L., Feiner, A., \& Viehs, M. (2015). From the Stockholder to the Stakeholder: How Sustainability Can Drive Financial Outperformance. Rochester, NY: Social Science Research Network. https://doi.org/10.2139/ssrn.2508281

Collison, D. J., Cobb, G., Power, D. M., \& Stevenson, L. A. (2008). The Financial Performance of the FTSE4Good Indices. Corporate Social Responsibility and Environmental Management, 15, 14-28. https://doi.org/10.1002/csr.144

Collison, D., Cobb, G., Power, D., \& Stevenson, L. (2009). FTSE4Good: Exploring Its Implications for Corporate Conduct. Accounting, Auditing \& Accountability Journal, 22, 35-58. https://doi.org/10.1108/09513570910923006

Corson, B. C., \& van Dyck, T. (1992). Socially Responsible Investing and Financial Return: Albatross or Scapegoat? The Journal of Investing, 1, 23-28.

https://doi.org/10.3905/joi.1.2.23

Cumming, D., \& Johan, S. (2007). Socially Responsible Institutional Investment in Private Equity. Journal of Business Ethics, 75, 395-416.

https://doi.org/10.1007/s10551-006-9261-8

Cummings, L. S. (2000). The Financial Performance of Ethical Investment Trusts: An Australian Perspective. Journal of Business Ethics, 25, 79-92. https://doi.org/10.1023/A:1006102802904

D’Antonio, L., Johnsen, T., \& Bruce Hutton, R. (1997). Expanding Socially Screened Portfolios: An Attribution Analysis of Bond Performance. The Journal of Investing, 6, 79-86. https://doi.org/10.3905/joi.1997.408434

D’Antonio, L., Johnsen, T., \& Hutton, B. (2000). Socially Responsible Investing and Asset Allocation. The Journal of Investing, 9, 65-72. https://doi.org/10.3905/joi.2000.319380

Dasgupta, S., Laplante, B., \& Mamingi, N. (2001). Pollution and Capital Markets in Developing Countries. Journal of Environmental Economics and Management, 42, 282-306. https://doi.org/10.1006/jeem.2000.1161

De Colle, S., \& York, J. G. (2009). Why Wine Is Not Glue? The Unresolved Problem of Negative Screening in Socially Responsible Investing. Journal of Business Ethics, 85, 83-95. https://doi.org/10.1007/s10551-008-9949-z

Demyanyk, Y., \& Van Hemert, O. (2011). Understanding the Subprime Mortgage Crisis. 
The Review of Financial Studies, 24, 1848-1880. https://doi.org/10.1093/rfs/hhp033

Derwall, J., Guenster, N., Bauer, R., \& Koedijk, K. (2005). The Eco-Efficiency Premium Puzzle. Financial Analyst Journal, 61, 51-63. https://doi.org/10.2469/faj.v61.n2.2716

Derwall, J., Koedijk, K., \& Ter Horst, J. (2011). A Tale of Values-Driven and Profit-Seeking Social Investors. Journal of Banking \& Finance, 35, 2137-2147. https://doi.org/10.1016/j.jbankfin.2011.01.009

DiBartolomeo, D., \& Kurtz, L. (1999). Managing Risk Exposures of Socially Screened Portfolios (pp. 1-17). Boston, MA: Northfield Information Services.

Dillenburg, S., Greene, T., \& Erekson, O. H. (2003). Approaching Socially Responsible Investment with a Comprehensive Ratings Scheme: Total Social Impact. Journal of Business Ethics, 43, 167-177. https://doi.org/10.1023/A:1022987127960

Dopierała, Ł., Mosionek-Schweda, M., \& Ilczuk, D. (2020). Does the Asset Allocation Policy Affect the Performance of Climate-Themed Funds? Empirical Evidence from the Scandinavian Mutual Funds Market. Sustainability, 12, 654.

https://doi.org/10.3390/su12020654

Dowell, G., Hart, S., \& Yeung, B. (2000). Do Corporate Global Environmental Standards Create or Destroy Market Value? Management Science, 46, 1059-1074. https://doi.org/10.1287/mnsc.46.8.1059.12030

Drut, B. (2010). Sovereign Bonds and Socially Responsible Investment. Journal of Business Ethics, 92, 131-145. https://doi.org/10.1007/s10551-010-0638-3

Duttweiler, R. (2011). Managing Liquidity in Banks: A Top down Approach. Hoboken, NJ: John Wiley \& Sons. https://doi.org/10.1002/9781119206415

Edmans, A. (2011). Does the Stock Market Fully Value Intangibles? Employee Satisfaction and Equity Prices. Journal of Financial Economics, 101, 621-640.

https://doi.org/10.1016/j.jfineco.2011.03.021

El Ghoul, S., \& Karoui, A. (2017). Does Corporate Social Responsibility Affect Mutual Fund Performance and Flows? Journal of Banking \& Finance, 77, 53-63. https://doi.org/10.1016/j.jbankfin.2016.10.009

El-Gamal, M. A. (2006). Islamic Finance: Law, Economics, and Practice. Cambridge: Cambridge University Press. https://doi.org/10.1017/CBO9780511753756

Epstein, M. J., \& Schnietz, K. E. (2002). Measuring the Cost of Environmental and Labor Protests to Globalization: An Event Study of the Failed 1999 Seattle WTO Talks. The International Trade Journal, 16, 129-160. https://doi.org/10.1080/08853900252901396

Fama, E. F., \& French, K. R. (1993). Common Risk Factors in the Returns on Stocks and Bonds. Journal of Financial Economics, 33, 3-56. https://doi.org/10.1016/0304-405X(93)90023-5

Friede, G., Busch, T., \& Bassen, A. (2015). ESG and Financial Performance: Aggregated Evidence from More than 2000 Empirical Studies. Journal of Sustainable Finance \& Investment, 5, 210-233. https://doi.org/10.1080/20430795.2015.1118917

Fung, H.-G., Law, S. A., \& Yau, J. (2010). Socially Responsible Investment in a Global Environment. Cheltenham: Edward Elgar Publishing. https://doi.org/10.4337/9781849805230

Galagedera, D. U. A. (2019). Modelling Social Responsibility in Mutual Fund Performance Appraisal: A Two-Stage Data Envelopment Analysis Model with Non-Discretionary First Stage Output. European Journal of Operational Research, 273, 376-389. https://doi.org/10.1016/j.ejor.2018.08.011

Gangi, F., \& Varrone, N. (2018). Screening Activities by Socially Responsible Funds: A Matter of Agency? Journal of Cleaner Production, 197, 842-855. 
https://doi.org/10.1016/j.jclepro.2018.06.228

Gatti, L., \& Seele, P. (2015). CSR through the CEO's Pen. Umwelt Wirtschafts Forum, 23, 265-277. https://doi.org/10.1007/s00550-015-0361-8

Geczy, C., Stambaugh, R. F., \& Levin, D. (2005). Investing in Socially Responsible Mutual Funds. Rochester, NY: Social Science Research Network.

Gharghori, P., \& Ooi, E. (2016). Chapter 16-The Relationship between Screening Intensity and Performance of Socially Responsible Investment Funds. In V. Ramiah, \& G. N. Gregoriou (Eds.), Handbook of Environmental and Sustainable Finance (pp. 335-357). San Diego: Academic Press. https://doi.org/10.1016/B978-0-12-803615-0.00016-9

Gil-Bazo, J., Ruiz-Verdú, P., \& Santos, A. A. P. (2010). The Performance of Socially Responsible Mutual Funds: The Role of Fees and Management Companies. Journal of Business Ethics, 94, 243-263. https://doi.org/10.1007/s10551-009-0260-4

Glac, K. (2014). The Influence of Shareholders on Corporate Social Responsibility. Economics, Management, and Financial Markets, 9, 34-79.

Goldreyer, E. F., \& Diltz, J. D. (1999). The Performance of Socially Responsible Mutual Funds: Incorporating Sociopolitical Information in Portfolio Selection. Managerial Finance, 25, 23-36. https://doi.org/10.1108/03074359910765830

Gompers, P., Ishii, J., \& Metrick, A. (2003). Corporate Governance and Equity Prices. The Quarterly Journal of Economics, 118, 107-156.

https://doi.org/10.1162/00335530360535162

Gregory, A., Matatko, J., \& Luther, R. (1997). Ethical Unit Trust Financial Performance: Small Company Effects and Fund Size Effects. Journal of Business Finance and Accounting, 24, 705-725. https://doi.org/10.1111/1468-5957.00130

Griseri, P., \& Seppala, N. (2010). Business Ethics and Corporate Social Responsibility. Boston, MA: Cengage Learning.

Grossman, B. R., \& Sharpe, W. F. (1986). Financial Implications of South African Divestment. Financial Analyst Journal, 42, 15-29. https://doi.org/10.2469/faj.v42.n4.15

GSIA (2018). Global Sustainable Investment Review 2018. Global Sustainable Investment Alliance.

Guay, T., Doh, J. P., \& Sinclair, G. (2004). Non-Governmental Organizations, Shareholder Activism, and Socially Responsible Investments: Ethical, Strategic, and Governance Implications. Journal of Business Ethics, 52, 125-139.

https://doi.org/10.1023/B:BUSI.0000033112.11461.69

Guerard, J. B. (1997). Additional Evidence on the Cost of Being Socially Responsible in Investing. The Journal of Investing, 6, 31-36. https://doi.org/10.3905/joi.1997.408433

Gutsche, G., \& Zwergel, B. (2020). Investment Barriers and Labeling Schemes for Socially Responsible Investments. Schmalenbach Business Review, 1-47. https://doi.org/10.1007/s41464-020-00085-Z

Hamilton, J. T. (1995). Pollution as News: Media and Stock Market Reactions to the Toxics Release Inventory Data. Journal of Environmental Economics and Management, 28, 98-113. https://doi.org/10.1006/jeem.1995.1007

Hamilton, S., Jo, H., \& Statman, M. (1993). Doing Well While Doing Good? The Investment Performance of Socially Responsible Mutual Funds. Financial Analyst Journal, 49, 62-66. https://doi.org/10.2469/faj.v49.n6.62

Heiduk, G., \& McCaleb, A. (2014). CSR Strategies in Greater China: Global, East Asian, American, European Style? International Journal of Management and Economics, 37, 169-189. https://doi.org/10.2478/ijme-2014-0009 
Henke, H.-M. (2016). The Effect of Social Screening on Bond Mutual Fund Performance. Journal of Banking \& Finance, 67, 69-84. https://doi.org/10.1016/j.jbankfin.2016.01.010

Hill, J. (2020). Chapter 9-Defining and Measuring ESG Performance. In J. Hill (Ed.), Environmental, Social, and Governance (ESG) Investing (pp. 167-183). Cambridge, MA: Academic Press. https://doi.org/10.1016/B978-0-12-818692-3.00009-8

Hill, R. P., Ainscough, T., Shank, T., \& Manullang, D. (2007). Corporate Social Responsibility and Socially Responsible Investing: A Global Perspective. Journal of Business Ethics, 70, 165-174. https://doi.org/10.1007/s10551-006-9103-8

Hockerts, K., \& Moir, L. (2004). Communicating Corporate Responsibility to Investors: The Changing Role of the Investor Relations Function. Journal of Business Ethics, 52, 85-98. https://doi.org/10.1023/B:BUSI.0000033109.35980.16

Hong, H., \& Kostovetsky, L. (2012). Red and Blue Investing: Values and Finance. Journal of Financial Economics, 103, 1-19. https://doi.org/10.1016/j.jfineco.2011.01.006

Humphrey, J. E., \& Lee, D. D. (2011). Australian Socially Responsible Funds: Performance, Risk and Screening Intensity. Journal of Business Ethics, 102, 519-535.

https://doi.org/10.1007/s10551-011-0836-7

Humphrey, J. E., Lee, D. D., \& Shen, Y. (2012). Does It Cost to Be Sustainable? Journal of Corporate Finance, 18, 626-639. https://doi.org/10.1016/j.jcorpfin.2012.03.002

Ibikunle, G., \& Steffen, T. (2017). European Green Mutual Fund Performance: A Comparative Analysis with their Conventional and Black Peers. Journal of Business Ethics, 145, 337-355. https://doi.org/10.1007/s10551-015-2850-7

Ielasi, F., \& Rossolini, M. (2019). Responsible or Thematic? The True Nature of Sustainability-Themed Mutual Funds. Sustainability, 11, 3304. https://doi.org/10.3390/su11123304

Iqbal, Z., \& Mirakhor, A. (2011). An Introduction to Islamic Finance: Theory and Practice. Hoboken, NJ: John Wiley \& Sons. https://doi.org/10.1002/9781118390474

Ito, Y., Managi, S., \& Matsuda, A. (2013). Performances of Socially Responsible Investment and Environmentally Friendly Funds. Journal of the Operational Research Society, 64, 1583-1594. https://doi.org/10.1057/jors.2012.112

Jegadeesh, N., \& Titman, S. (1993). Returns to Buying Winners and Selling Losers: Implications for Stock Market Efficiency. The Journal of Finance, 48, 65-91. https://doi.org/10.1111/j.1540-6261.1993.tb04702.x

Jégourel, Y., \& Maveyraud, L. S. (2008). The Financial Performance of Solidarity Investment Funds: The French Case.

Jensen, M. C. (1967). The Performance of Mutual Funds in the Period 1945-1964. Journal of Finance, 23, 389-416. https://doi.org/10.1111/j.1540-6261.1968.tb00815.x

Joliet, R., \& Titova, Y. (2018). Equity SRI Funds Vacillate between Ethics and Money: An Analysis of the Funds' Stock Holding Decisions. Journal of Banking \& Finance, 97, 70-86. https://doi.org/10.1016/j.jbankfin.2018.09.011

Jones, R., \& Murrell, A. J. (2001). Signaling Positive Corporate Social Performance. Business and Society, 40, 59-78. https://doi.org/10.1177/000765030104000105

Jones, S., Vander Laan, S., Frost, G., \& Loftus, J. (2008). The Investment Performance of Socially Responsible Investment Funds in Australia. Journal of Business Ethics, 80, 181-203. https://doi.org/10.1007/s10551-007-9412-6

Judge, W. Q., \& Douglas, T. J. (1998). Performance Implications of Incorporating Natural Environmental Issues into the Strategic Planning Process: An Empirical Assessment. The Journal of Management Studies, 35, 241-262. https://doi.org/10.1111/1467-6486.00092 
Junkus, J. C., \& Berry, T. C. (2010). The Demographic Profile of Socially Responsible Investors. Managerial Finance, 36, 474-481. https://doi.org/10.1108/03074351011042955

Kahn, R. N., Lekander, C., \& Leimkuhler, T. (1997). Just Say No? The Investment Implications of Tobacco Divestiture. The Journal of Investing, 6, 62-70. https://doi.org/10.3905/joi.1997.62

Kempf, A., \& Osthoff, P. (2007). The Effect of Socially Responsible Investing on Portfolio Performance. European Financial Management, 13, 908-922. https://doi.org/10.1111/j.1468-036X.2007.00402.x

Kirchhoff, K. R. (2008). Investor Relations. In A. Habisch, M. Neureiter, \& R. Schmidpeter (Eds.), Handbuch Corporate Citizenship: Corporate Social Responsibility für Manager (pp. 109-116). Berlin: Springer. https://doi.org/10.1007/978-3-540-36358-3 7

Kiymaz, H. (2019a). Factors Influencing SRI Fund Performance. Journal of Capital Markets Studies, 3, 68-81. https://doi.org/10.1108/JCMS-04-2019-0016

Kiymaz, H. (2019b). Performance Evaluation of SRI Funds: An Analysis of Fund Types. https://doi.org/10.5430/afr.v8n1p212

Klaasen, R. D., \& McLaughlin, C. P. (1996). The Impact of Environmental Management on Firm Performance. Management Science, 42, 1199-1214.

https://doi.org/10.1287/mnsc.42.8.1199

Kolk, A. (2016). The Social Responsibility of International Business: From Ethics and the Environment to CSR and Sustainable Development. Journal of World Business, 51, 23-34. https://doi.org/10.1016/j.jwb.2015.08.010

Konar, S., \& Cohen, M. A. (1997). Information as Regulation: The Effect of Community Right to Know Laws on Toxic Emissions. Journal of Environmental Economics and Management, 32, 109-124. https://doi.org/10.1006/jeem.1996.0955

Konar, S., \& Cohen, M. A. (2001). Does the Market Value Environmental Performance? The Review of Economics and Statistics, 83, 281-289. https://doi.org/10.1162/00346530151143815

Kreander, N., Gray, R. H., Power, D. M., \& Sinclair, C. D. (2005). Evaluating the Performance of Ethical and Non-Ethical Funds: A Matched Pair Analysis. Journal of Business Finance and Accounting, 32, 1465-1493. https://doi.org/10.1111/j.0306-686X.2005.00636.x

Kurtz, L., \& diBartolomeo, D. (2005). The KLD Catholic Values 400 Index. The Journal of Investing, 14, 101-104. https://doi.org/10.3905/joi.2005.580556

Lean, H. H., Ang, W. R., \& Smyth, R. (2015). Performance and Performance Persistence of Socially Responsible Investment Funds in Europe and North America. The North American Journal of Economics and Finance, 34, 254-266. https://doi.org/10.1016/j.najef.2015.09.011

Leca, B., Déjean, F., Huault, I., \& Gond, J. P. (2019). The Role of Artifacts in Institutionalization Process: Insights from the Development of Socially Responsible Investment in France. In F.-X. de Vaujany, A. Adrot, E. Boxenbaum, \& B. Leca (Eds.), Materiality in Institutions: Spaces, Embodiment and Technology in Management and Organization (pp. 73-107). Cham: Springer International Publishing. https://doi.org/10.1007/978-3-319-97472-9 4

Leite, P., \& Cortez, M. C. (2014). Style and Performance of International Socially Responsible Funds in Europe. Research in International Business and Finance, 30, 248-267. https://doi.org/10.1016/j.ribaf.2013.09.007

Leite, P., \& Cortez, M. C. (2015). Performance of European Socially Responsible Funds during Market Crises: Evidence from France. International Review of Financial Analy- 
sis, 40, 132-141. https://doi.org/10.1016/j.irfa.2015.05.012

Lesser, K., Rößle, F., \& Walkshäusl, C. (2016). Socially Responsible, Green, and Faith-Based Investment Strategies: Screening Activity Matters! Finance Research Letters, 16, 171-178. https://doi.org/10.1016/j.frl.2015.11.001

Longstaff, F. A. (2010). The Subprime Credit Crisis and Contagion in Financial Markets. Journal of Financial Economics, 97, 436-450. https://doi.org/10.1016/j.jfineco.2010.01.002

López, M. V., Garcia, A., \& Rodriguez, L. (2007). Sustainable Development and Corporate Performance: A Study Based on the Dow Jones Sustainability Index. Journal of Business Ethics, 75, 285-300. https://doi.org/10.1007/s10551-006-9253-8

Lozano, J. M., Albareda, L., \& Balaguer, M. R. (2006). Socially Responsible Investment in the Spanish financial market. Journal of Business Ethics, 69, 305-316. https://doi.org/10.1007/s10551-006-9092-7

Luther, R. G., \& Matatko, J. (1994). The Performance of Ethical Unit Trusts: Choosing an Appropriate Benchmark. The British Accounting Review, 26, 77-89.

https://doi.org/10.1006/bare.1994.1007

Luther, R. G., Matatko, J., \& Corner, D. C. (1992). The Investment Performance of UK "Ethical" Unit Trusts. Accounting, Auditing and Accountability Journal, 5, 57-70. https://doi.org/10.1108/09513579210019521

Mallin, C. A., Saadouni, B., \& Briston, R. J. (1995). The Financial Performance of Ethical Investment Funds. Journal of Business Finance and Accounting, 22, 483-496. https://doi.org/10.1111/j.1468-5957.1995.tb00373.x

Markham, J. W. (2015). A Financial History of the United States: From Enron-Era Scandals to the Subprime Crisis (2004-2006). From the Subprime Crisis to the Great Recession (2006-2009). Abingdon-on-Thames: Routledge. https://doi.org/10.4324/9781315706863

Markowitz, H. (1952). Portfolio Selection. The Journal of Finance, 7, 77-91. https://doi.org/10.1111/j.1540-6261.1952.tb01525.x

Martí-Ballester, C.-P. (2015). Can Socially Responsible Investment for Cleaner Production Improve the Financial Performance of Spanish Pension Plans? Journal of Cleaner Production, 106, 466-477. https://doi.org/10.1016/j.jclepro.2014.06.058

Martin Curran, M., \& Moran, D. (2007). Impact of the FTSE4Good Index on Firm Price: An Event Study. Journal of Environmental Management, 82, 529-537. https://doi.org/10.1016/j.jenvman.2006.02.010

Miglietta, A. (2004). Some Theoretical Topics on the Diffusion of Innovation within Industrial Districts: The Case of ICT. Moncalieri: Institute for Economic Research on Firms and Growth; Italy-Now-Research Institute on Sustainable Economic Growth.

Mill, G. A. (2006). The Financial Performance of a Socially Responsible Investment over Time and a Possible Link with Corporate Social Responsibility. Journal of Business Ethics, 63, 131. https://doi.org/10.1007/s10551-005-2410-7

Mueller, S. A. (1991). The Opportunity Cost of Discipleship: Ethical Mutual Funds and Their Performance. Sociological Analysis, 52, 111-124. https://doi.org/10.2307/3710719

Nilsson, J. (2008). Investment with a Conscience: Examining the Impact of Pro-Social Attitudes and Perceived Financial Performance on Socially Responsible Investment Behavior. Journal of Business Ethics, 83, 307-325. https://doi.org/10.1007/s10551-007-9621-Z

Nofsinger, J., \& Varma, A. (2014). Socially Responsible Funds and Market Crises. Journal of Banking \& Finance, 48, 180-193. https://doi.org/10.1016/j.jbankfin.2013.12.016 
Ogden, S., \& Watson, R. (1999). Corporate Performance and Stakeholder Management: Balancing Shareholder and Customer Interests in the UK Privatized Water Industry. Academy of Management Journal, 42, 526-538. https://doi.org/10.2307/256974

Omri, A., Soussou, K., \& Goucha, N. B. S. (2019). On the Post-Financial Crisis Performance of Islamic Mutual Funds: The Case of Riyad Funds. Applied Economics, 51, 1929-1946. https://doi.org/10.1080/00036846.2018.1529403

Peifer, J. L. (2012). Socially Responsible Investing and the Power to Do Good: Whose Dollars Are Being Heard? In A. L. Keister, J. Mccarthy, \& R. Finke (Eds.), Religion, Work and Inequality (pp. 103-129). Bingley: Emerald Group Publishing Limited. https://doi.org/10.1108/S0277-2833(2012)0000023008

Pereira, A. V. de S. (2020). The Subprime Crisis Effects in Leverage Mechanisms.

Petrillo, A., De Felice, F., García-Melón, M., \& Pérez-Gladish, B. (2016). Investing in Socially Responsible Mutual Funds: Proposal of Non-Financial Ranking in Italian Market. Research in International Business and Finance, 37, 541-555. https://doi.org/10.1016/j.ribaf.2016.01.027

Pirgaip, B., Arslan-Ayaydin, Ö., \& Karan, M. B. (2020). Do Sukuk Provide Diversification Benefits to Conventional Bond Investors? Evidence from Turkey. Global Finance Journal, Article ID: 100533. https://doi.org/10.1016/j.gfj.2020.100533

Ramchander, S., Schwebach, R. G., \& Staking, K. I. M. (2012). The Informational Relevance of Corporate Social Responsibility: Evidence from DS400 Index Reconstitutions. Strategic Management Journal, 33, 303-314. https://doi.org/10.1002/smj.952

Rathner, S. (2013). The Influence of Primary Study Characteristics on the Performance Differential between Socially Responsible and Conventional Investment Funds: A Meta-Analysis. Journal of Business Ethics, 118, 349-363. https://doi.org/10.1007/s10551-012-1584-Z

Reddy, K., Mirza, N., Naqvi, B., \& Fu, M. (2017). Comparative Risk Adjusted Performance of Islamic, Socially Responsible and Conventional Funds: Evidence from United Kingdom. Economic Modelling, 66, 233-243.

https://doi.org/10.1016/j.econmod.2017.07.007

Renneboog, L., Ter Horst, J., \& Zhang, C. (2008). Socially Responsible Investments: Institutional Aspects, Performance, and Investor Behavior. Journal of Banking \& Finance, 32, 1723-1742. https://doi.org/10.1016/j.jbankfin.2007.12.039

Revelli, C (2016). Re-Embedding Financial Stakes within Ethical and Social Values in Socially Responsible Investing (SRI). Research in International Business and Finance, 38, 1-5. https://doi.org/10.1016/j.ribaf.2016.03.003

Sauer, D. A. (1997). The Impact of Social-Responsibility Screens on Investment Performance: Evidence from the Domini 400 Social Index and Domini Equity Mutual Fund. Review of Financial Economics, 6, 137-149. https://doi.org/10.1016/S1058-3300(97)90002-1

Schröder, M. (2004). The Performance of Socially Responsible Investments: Investment Funds and Indices. Financial Markets and Portfolio Management, 18, 122-142. https://doi.org/10.1007/s11408-004-0202-1

Searcy, C., \& Elkhawas, D. (2012). Corporate Sustainability Ratings: An Investigation into How Corporations Use the Dow Jones Sustainability Index. Journal of Cleaner Production, 35, 79-92. https://doi.org/10.1016/j.jclepro.2012.05.022

Shahzad, M., Qu, Y., Javed, S. A. et al (2020). Relation of Environment Sustainability to CSR and Green Innovation: A Case of Pakistani Manufacturing Industry. Journal of Cleaner Production, 253, Article ID: 119938. 
https://doi.org/10.1016/j.jclepro.2019.119938

Shank, T., Manullang, D., \& Hill, R. P. (2005). “Doing Well While Doing Good” Revisited: A Study of Socially Responsible Firms' Short-Term versus Long-Term Performance. Managerial Finance, 30, 33-46. https://doi.org/10.1108/03074350510769794

Sharpe, W. F. (1966). Mutual Fund Performance. The Journal of Business, 39, 119-138. https://doi.org/10.1086/294846

Silva, F., \& Cortez, M. C. (2016). The Performance of US and European Green Funds in Different Market Conditions. Journal of Cleaner Production, 135, 558-566. https://doi.org/10.1016/j.jclepro.2016.06.112

Statman, M. (2000). Socially Responsible Mutual Funds (Corrected). Financial Analysts Journal, 56, 30-39. https://doi.org/10.2469/faj.v56.n3.2358

Statman, M. (2006). Socially Responsible Indexes. The Journal of Portfolio Management, 32, 100-109. https://doi.org/10.3905/jpm.2006.628411

Syed, A. M. (2017). Socially Responsible: Are They Profitable? Research in International Business and Finance, 42, 1504-1515. https://doi.org/10.1016/j.ribaf.2017.07.090

Taleb, L., \& Khouaja, D. (2019). Crise des Subprimes, Réglementation Prudentielle: Z-score ou Rating? Une Étude sur Des Banques De La Zone Euro (Subprime Crisis, Prudential Regulatory: Z-Score or Rating? A Study on Banks of the Eurozone). Rochester, NY: Social Science Research Network. https://doi.org/10.2139/ssrn.3359290

Teoh, H. Y., \& Shiu, G. Y. (1990). Attitudes towards Corporate Social Responsibility and Perceived Importance of Social Responsibility Information Characteristics in a Decision Context. Journal of Business Ethics, 9, 71-77. https://doi.org/10.1007/BF00382566

Teoh, S. H., Welch, I., \& Wazzan, C. P. (1999). The Effect of Socially Activist Investment Policies on the Financial Markets: Evidence from the South African Boycott. The Journal of Business, 72, 35-89. https://doi.org/10.1086/209602

Teper, J. A. (1992). Evaluating the Cost of Socially Responsible Investing. In P. D. Kinder, S. D. Lydenberg, \& A. L. Domini (Eds.), The Social Investment Almanac: A Comprehensive Guide to Socially Responsible Investing (pp. 340-349). New York: Henry Holt and Company.

Tobin, J. (1969). A General Equilibrium Approach to Monetary Theory. Journal of Money, Credit and Banking, 1, 15-29. https://doi.org/10.2307/1991374

Travers, F. J. (1997). Socially Responsible Investing on a Global Basis: Mixing Money and Morality outside the US. The Journal of Investing, 6, 50-56. https://doi.org/10.3905/joi.1997.408437

Treynor, J. L. (1965). How to Rate Management of Investment Funds. Harvard Business Review, 43, 63-75.

Trinks, P. J., \& Scholtens, B. (2017). The Opportunity Cost of Negative Screening in Socially Responsible Investing. Journal of Business Ethics, 140, 193-208.

https://doi.org/10.1007/s10551-015-2684-3

Umlas, E. (2008). The Global Expansion of SRI: Facing Challenges, Meeting Potential. Development and Change, 39, 1019-1036. https://doi.org/10.1111/j.1467-7660.2008.00527.x

Verschoor, C. C. (1998). A Study of the Link between a Corporation's Financial Performance and Its Commitment to Ethics. Journal of Business Ethics, 17, 1509-1516. https://doi.org/10.1023/A:1006020402881

Visser, H. (2019). Islamic Finance: Principles and Practice (3rd ed.). Cheltenham: Edward Elgar Publishing. 
Waddock, S. A., \& Graves, S. B. (1997). Finding the Link between Stakeholder Relations and Quality of Management. The Journal of Investing, 6, 20-24.

https://doi.org/10.3905/joi.1997.408435

Warde, I. (2000). Islamic Finance in the Global Economy. Edinburgh: Edinburgh University Press. https://doi.org/10.3366/edinburgh/9780748612161.001.0001

Whitehouse, L. (2006). Corporate Social Responsibility: Views from the Frontline. Journal of Business Ethics, 63, 279-296. https://doi.org/10.1007/s10551-005-3243-0

Wright, P., \& Ferris, S. P. (1997). Agency Conflict and Corporate Strategy: The Effect of Divestment on Corporate Value. Strategic Management Journal, 18, 77-83.

https://doi.org/10.1002/(SICI)1097-0266(199701)18:1<77::AID-SMJ810>3.0.CO;2-R 